BMC

Microbiology

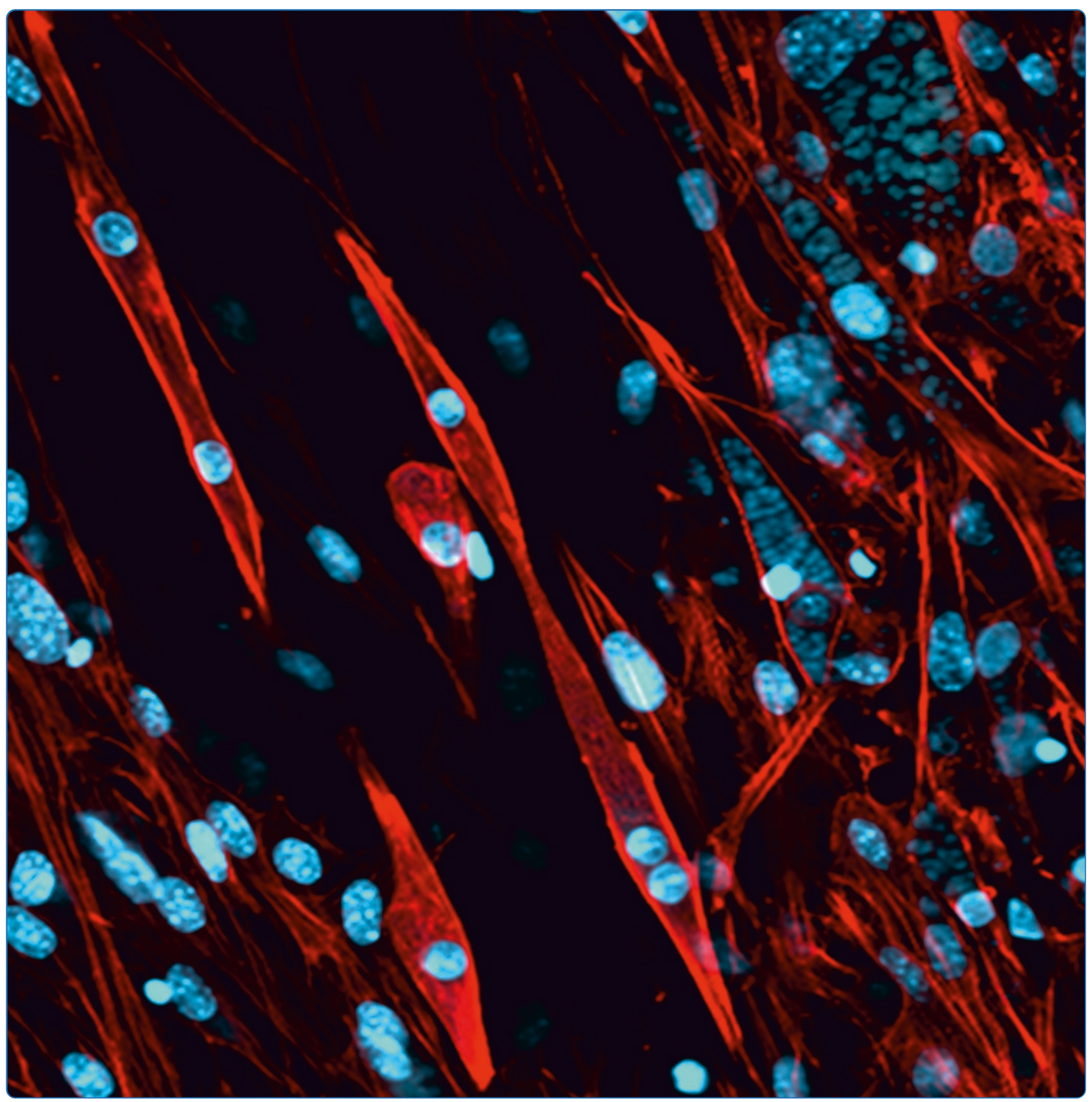

Toxoplasma gondii down modulates cadherin expression in skeletal muscle cells inhibiting myogenesis

Gomes et al. 


\title{
Toxoplasma gondii down modulates cadherin expression in skeletal muscle cells inhibiting myogenesis
}

\author{
Alessandra F Gomes ${ }^{1}$, Erick V Guimarães', Laís Carvalho², José R Correa', Leila Mendonça-Lima ${ }^{3}$ and \\ Helene S Barbosa ${ }^{1 *}$
}

\begin{abstract}
Background: Toxoplasma gondii belongs to a large and diverse group of obligate intracellular parasitic protozoa. Primary culture of mice skeletal muscle cells (SkMC) was employed as a model for experimental toxoplasmosis studies. The myogenesis of SkMC was reproduced in vitro and the ability of T. gondii tachyzoite forms to infect myoblasts and myotubes and its influence on SkMC myogenesis were analyzed.

Results: In this study we show that, after $24 \mathrm{~h}$ of interaction, myoblasts (61\%) were more infected with T. gondii than myotubes (38\%) and inhibition of myogenesis was about $75 \%$. The role of adhesion molecules such as cadherin in this event was investigated. First, we demonstrate that cadherin localization was restricted to the contact areas between myocytes/myocytes and myocytes/myotubes during the myogenesis process. Immunofluorescence and immunoblotting analysis of parasite-host cell interaction showed a 54\% reduction in cadherin expression at $24 \mathrm{~h}$ of infection. Concomitantly, a reduction in M-cadherin mRNA levels was observed after 3 and $24 \mathrm{~h}$ of $T$. gondii-host cell interaction.

Conclusions: These data suggest that $T$. gondii is able to down regulate M-cadherin expression, leading to molecular modifications in the host cell surface that interfere with membrane fusion and consequently affect the myogenesis process.
\end{abstract}

Keywords: Toxoplasma gondii myogenesis, cadherin, skeletal muscle cells, T. gondii-host cell interaction

\section{Background}

Toxoplasma gondii is an obligatory intracellular parasite and an important human pathogen. Humans acquire toxoplasmosis due to oocyst seeding from cats, consumption of raw or undercooked meat or vertical transmission to the fetus during pregnancy. Studies of environmental factors in several communities indicated an important role for cultural and eating habits on this infection transmission [1]. During natural vertical infections, Toxoplasma initially crosses the intestinal epithelium of the mother, disseminates into the deep tissues and traverses the placenta, the blood-brain and the blood-retina barriers [2]. In both immunocompromised

\footnotetext{
* Correspondence: helene@ioc.fiocruz.br

'Laboratório de Biologia Estrutural, Instituto Oswaldo Cruz, Fundação

Oswaldo Cruz, (Av. Brasil 4365), Rio de Janeiro (21040-361), Brazil

Full list of author information is available at the end of the article
}

and immunocompetent individuals, Toxoplasma infection can cause a severe ocular pathology $[3,4]$. These parasites are able to invade and rapidly replicate in any nucleated host cell and may develop cysts, predominantly in neural and muscular tissues, initiating the chronic infection stage.

Until now little attention has been given to skeletal muscle as a model in experimental toxoplasmosis studies [5-9], though skeletal muscle is one of the main sites for the occurrence of cystogenesis [10].

It is established that toxoplasmosis can cause myositis either by recent infection or by infection reactivation, causing muscle injury and release of parasites in the bloodstream $[11,12]$. The involvement of muscular tissue in the chronic stage of toxoplasmosis is a significant clinical aspect for immunodeficient individuals infected with the HIV virus, and can be employed in biopsies for
C Biomed Central

() 2011 Gomes et al; licensee BioMed Central Ltd. This is an Open Access article distributed under the terms of the Creative Commons Attribution License (http://creativecommons.org/licenses/by/2.0), which permits unrestricted use, distribution, and reproduction in any medium, provided the original work is properly cited. 
diagnosis, as proposed by [13]. In addition, one case of polymyositis in an immunocompetent patient diagnosed with acquired toxoplasmosis has been reported [14]. The interaction of $T$. gondii and primary cultures of skeletal muscle cells has been exploited by our group. This model reproduces important characteristics of the in vivo infection and also allows in vitro cystogenesis analysis [5-9,15-17]. The dynamics of SkMC cultures obtained from mouse embryos allows the investigation of each myogenesis stage $[18,19]$.

The adhesive contact regulation between cells underlies many morphogenetic processes during the development of new tissues and the controlled growth and turnover of adult tissues. The cell-cell physical interaction that occurs during myogenesis is carried out by cellular adhesion molecules. However, cadherins, comprising a family of adhesion molecules, are particularly important to the dynamic regulation of adherent junctions, which are associated with diverse morphogenetic processes [20]. Several intracellular pathogens able to modulate adhesion molecules on this junction during the infectious process may cause tissue pathogenesis [21-25]. During the myogenesis process, M-cadherins ( $\mathrm{M}$ for muscle) are involved in the initial cell-cell recognition, allowing initiation of myoblast fusion to form multinucleated myotubes [26,27], as demonstrated by the RNA interference method [28].

In the present study, we examined: (i) T. gondii tachyzoite capacity to infect SkMC (myoblasts and myotubes); (ii) the influence of $T$. gondii infection on myogenesis process; (iii) the parasite's impact on SkMC M-cadherin expression and, (iv) its correlation with myogenesis process.

\section{Methods}

All procedures were carried out in accordance with the guidelines established by the Colégio Brasileiro de Experimentação Animal (COBEA), by Fundação Oswaldo Cruz-Fiocruz, Committee of Ethics for the Use of Animals (license CEUA LW 10/10) and by Guidelines on the Cared and Use of Animals for Experimental Purposes and Infectious Agents (NACLAR).

\section{Primary culture of skeletal muscle cells}

SkMC cultures were obtained from thigh muscles of 18day-old mouse embryos. The tissues were minced and incubated for $7 \mathrm{~min}$ with $0.05 \%$ trypsin and $0.01 \%$ versene diluted in phosphate-buffered saline pH 7.2 (PBS). After 5-7 dissociation cycles, the enzymatic digestion was interrupted by addition of $10 \%$ fetal bovine serum at $4{ }^{\circ} \mathrm{C}$. The suspension was centrifuged at $650 \mathrm{~g}$ for 7 min, resuspended in Dulbecco's modified Eagle medium (DMEM) supplemented with $10 \%$ horse serum, $5 \%$ fetal bovine serum, $2 \%$ chick embryo extract, $1 \mathrm{mM}$
$L$-glutamine, 1,000 U/mL penicillin, $50 \mu \mathrm{g} / \mathrm{mL}$ streptomycin and then incubated for $30 \mathrm{~min}$ at $37^{\circ} \mathrm{C}$ in a $5 \%$ $\mathrm{CO}_{2}$ atmosphere. After incubation, the culture flask was gently shaken to release non-attached cells and the supernatant enriched with myoblasts was seeded in $0.02 \%$ gelatin-treated 24-well culture plates for the fluorescence assays. The cultures were maintained at $37^{\circ} \mathrm{C}$ up to 2-5 days to obtain the muscle fibers and fresh culture medium was added every two days.

\section{Parasites}

Tachyzoites of $T$. gondii, RH strain, were maintained in Swiss mice by serial intraperitoneal inoculation of $10^{5}$ parasites. After 48-72 h the parasites were harvested in PBS and centrifuged (200 g for 7-10 min) at room temperature in order to discard blood cells and cellular debris. The supernatant was collected and then centrifuged again at $1000 \mathrm{~g}$ for $10 \mathrm{~min}$. The final pellet was resuspended in DMEM and used in the interaction assays.

\section{T. gondii infection during skeletal muscle cell myogenesis} Aiming to verify the infectivity of $T$. gondii in myoblasts and myotubes, we developed the following protocol: 2day-old cultures were infected with tachyzoite forms (1:1 parasite-host cell ratio) and, after $24 \mathrm{~h}$ of interaction, the total number of infected myoblasts and myotubes was quantified independent of the number of internalized parasites.

For evaluation of the potential interference of $T$. gondii in myotube formation, after the initial seeding, cultures were maintained for $48 \mathrm{~h}$ in medium without calcium, in order to not stimulate myoblast fusion. After this time, the cultures, enriched in myoblasts, were infected for $24 \mathrm{~h}$. Cell fusion in the presence or absence of $T$. gondii was determined by morphological analysis of myoblast alignment and the observation of the percentage of multinucleated cells.

The quantitative analysis was based on 3 independent experiments performed in duplicate with at least 200 cells in each coverslip.

\section{Fluorescence analysis of actin microfilaments}

SkMC 2-day-old cultures were allowed to interact with tachyzoites (1:1 parasite: host cell ratio) for 24 and $48 \mathrm{~h}$ at $37^{\circ} \mathrm{C}$. Non-infected and infected SkMC were fixed for $5 \mathrm{~min}$ at room temperature in $4 \%$ paraformaldehyde (PFA) diluted in PBS. After fixation, the cultures were washed 3 times (10 min each) in the same buffer. Then, the cultures were incubated for $1 \mathrm{~h}$ at $37^{\circ} \mathrm{C}$ with $4 \mu \mathrm{g}$ / $\mathrm{ml}$ phalloidin-rhodamine diluted in PBS. Thereafter, the cultures were washed 3 times (10 min each) in PBS, incubated for $5 \mathrm{~min}$ in $0.1 \mu \mathrm{g} / \mathrm{mL}$ DAPI (4',6-diamidino2-phenylindole, Sigma Chemical Co.), a DNA stain that enables the visualization of host and parasite nuclei, and 
washed again in PBS. The coverslips were mounted on slides with a solution of 2.5\% DABCO (1,4-diazabicyclo[2]-octane-triethylenediamine antifading, Sigma Chemical Co.) in PBS containing 50\% glycerol, pH 7.2. The samples were examined in a confocal laser scanning microscope (CLSM Axiovert 510, META, Zeiss, Germany) from the Confocal Microscopy Plataform/PDTIS/ Fiocruz, using a 543 helium laser (LP560 filter) and 405 Diiod laser (LP 420 filter).

\section{Immunofluorescence analysis of total cadherin protein distribution in SkMC myogenesis during infection with $T$. gondii}

Immunofluorescence assays were performed using specific monoclonal antibodies for pan-cadherin (Sigma Chemical Co. C3678). Briefly, tachyzoite forms were allowed to interact with 2-day-old SkMC in the ratio of $1: 1$. After 3, 12, and $24 \mathrm{~h}$ of interaction, the cultures were fixed for $5 \mathrm{~min}$ at room temperature in $4 \%$ paraformaldehyde diluted in PBS and then washed 3 times $(10 \mathrm{~min}$ each) with PBS. The cultures were incubated for $1 \mathrm{~h}$ at room temperature in blocking solution containing $4 \%$ bovine serum albumin (BSA) and $0.5 \%$ Triton X100 (Sigma Chemical Co.) in PBS, followed by incubation overnight at $37^{\circ} \mathrm{C}$ with anti-pan cadherin antibody diluted 1:200 in PBS/BSA. The cultures were washed 3 times (10 min each) in PBS/BSA and incubated for $1 \mathrm{~h}$ at $37^{\circ} \mathrm{C}$ with Alexa Fluor 488, goat anti-rabbit IgG (Invitrogen, Molecular Probes) diluted 1:1000 in PBS/BSA. Coverslips were subsequently washed 3 times $(10 \mathrm{~min}$ each) in PBS, incubated for $10 \mathrm{~min}$ in $0.1 \mu \mathrm{g} / \mathrm{mL}$ DAPI and washed again in PBS. Coverslips were mounted on slides and examined by confocal microscopy as described above. Controls were performed by omission of the primary antibody.

\section{Western blot analysis}

For western blot analysis of total cadherin pool, the proteins were extracted from the following samples: (a) 2day-old SkMC to observe the protein synthesis pattern before infection; (b) 3-day-old SkMC (uninfected control) and, (c) SkMC infected with T. gondii tachyzoites (1:1 parasite:host-cell ratio), $24 \mathrm{~h}$ after infection (to study the possible impact of $T$. gondii infection in cadherin expression). Cadherin expression by $T$. gondii protozoan alone was also verified by western blot assays.

Cells were washed with PBS and maintained in ice for protein extraction. Briefly, cells were collected in approximately $600 \mathrm{uL}$ of lysis buffer $(50 \mathrm{mM}$ Tris- $\mathrm{Cl} \mathrm{pH}$ 8, $150 \mathrm{mM} \mathrm{NaCl}, 100 \mathrm{ug} / \mathrm{mL}$ PMSF, $1 \mathrm{mg} / \mathrm{mL}$ pepstatine. $1 \mathrm{mg} / \mathrm{mL}$ aprotinine, $10 \mathrm{mg} / \mathrm{mL}$ leupeptine in $1 \%$ Triton X-100, 0.4 mg/mL EGTA). Cell debris were removed by centrifugation, proteins in the cleared supernatant precipitated with cold acetone and resuspended in $8 \mathrm{M}$ ureum/2\% CHAPS. Total protein concentration was determined with the RC-DC kit (BioRad) prior to separation in 10\% SDS-PAGE gels. Proteins were electro-transferred to Hybond $\mathrm{C}$ membranes (GE Healthcare) with a Trans-Blot apparatus (BioRad), visualized by reversible staining with MemCode (Pierce) and the images captured in a GS-800 scanning densitometer (BioRad). Primary anti-Pan-cadherin mouse antibody (Sigma Chemical Co. C-1821) was used in a 1:2,000 dilution and bound antibodies were revealed using a peroxidase-coupled anti-mouse IgG antibody (Pierce 31430, 1:5,000 dilution). Blots were visualized with the SuperSignal West Pico chemiluminescence substrate (Pierce, 34080) and images captured as described above. For quantitative analysis, western blot signals were normalized against total proteins detected per lane in the corresponding MemCode stained membrane using the QuantityOne software (BioRad).

\section{RNA extraction and reverse transcription-PCR (RT-PCR)}

Total RNA was extracted from SkMC culture samples harvested at three different time points during the $T$. gondii infection assay $(3 \mathrm{~h}, 12 \mathrm{~h}$ and $24 \mathrm{~h})$. For this purpose, $10^{6}$ cells were harvested and washed three times in PBS and the pellet used for RNA extraction with the RNeasy kit (Qiagen California, CA, USA - 74104) according to the manufacture's recommendations. Reverse transcription was carried using $2 \mu \mathrm{g}$ of each RNA sample and the Mix reagents acquired from BioRad (California, USA - 170-8897), following the manufacture's instructions. For cDNA amplification, genespecific primers targeted to M-Cadherin [29] and GAPDH (glyceraldehyde 3-phosphate dehydrogenase) were used. PCR was carried out in a final volume of 10 $\mu \mathrm{L}$, with $1 \mu \mathrm{L}$ target $\mathrm{cDNA}, 5 \mathrm{pmol}$ of each primer, 200 $\mu \mathrm{M}$ each desoxyribonucleotide triphosphate (dNTP) (Promega, Wisconsin, USA), 0.8 units TaqDNA polymerase (Cenbiot, Rio Grande do Sul, Brazil) in a buffer containing $10 \mathrm{mM}$ Tris- $\mathrm{HCl}, \mathrm{pH} 8.5,50 \mathrm{mM} \mathrm{KCl}, 1.5$ $\mathrm{mM} \mathrm{MgCl}_{2}$ as previously described [30]. PCR analysis considered the gene expression of infected and uninfected host cells in relation to the internal control, GAPDH, as previously reported [31-35]. The samples were amplified for 30 cycles (denaturation at $94^{\circ} \mathrm{C}$ for $60 \mathrm{sec}$, annealing at $56^{\circ} \mathrm{C}$ or $54^{\circ} \mathrm{C}$ for $\mathrm{M}$-Cadherin and $\mathrm{GAPDH}$, respectively, and extension at $72^{\circ} \mathrm{C}$ for $60 \mathrm{sec}$ ). PCR products were visualized on $8 \%$ silver stained polyacrylamide gels. Gel images were acquired (Epson Perfection 4180 Photo, California, USA).

\section{Statistical analysis}

Densitometric analysis was performed using the Image J software (NIH) or Quantity One (BioRad, for western 
blot quantification). Student's $t$-test was used to determine the significance of differences between means in Western blot, RT-PCR and quantitative assays. A $p$ value $\leq 0.05$ was considered significant

\section{Results}

\section{T. gondii infectivity of SkMC}

Only the number of infected myoblasts and myotubes was evaluated, independently of the number of parasites internalized. The total number of infected cells (harboring at least one internalized parasite), after $24 \mathrm{~h}$ of SkMC - parasite interaction, represented $61 \%$ of myoblasts and $38 \%$ of myotubes. These data indicate that myotubes were 1.6-fold less infected than myoblasts (Figure 1A). Figure 1B shows young and mature

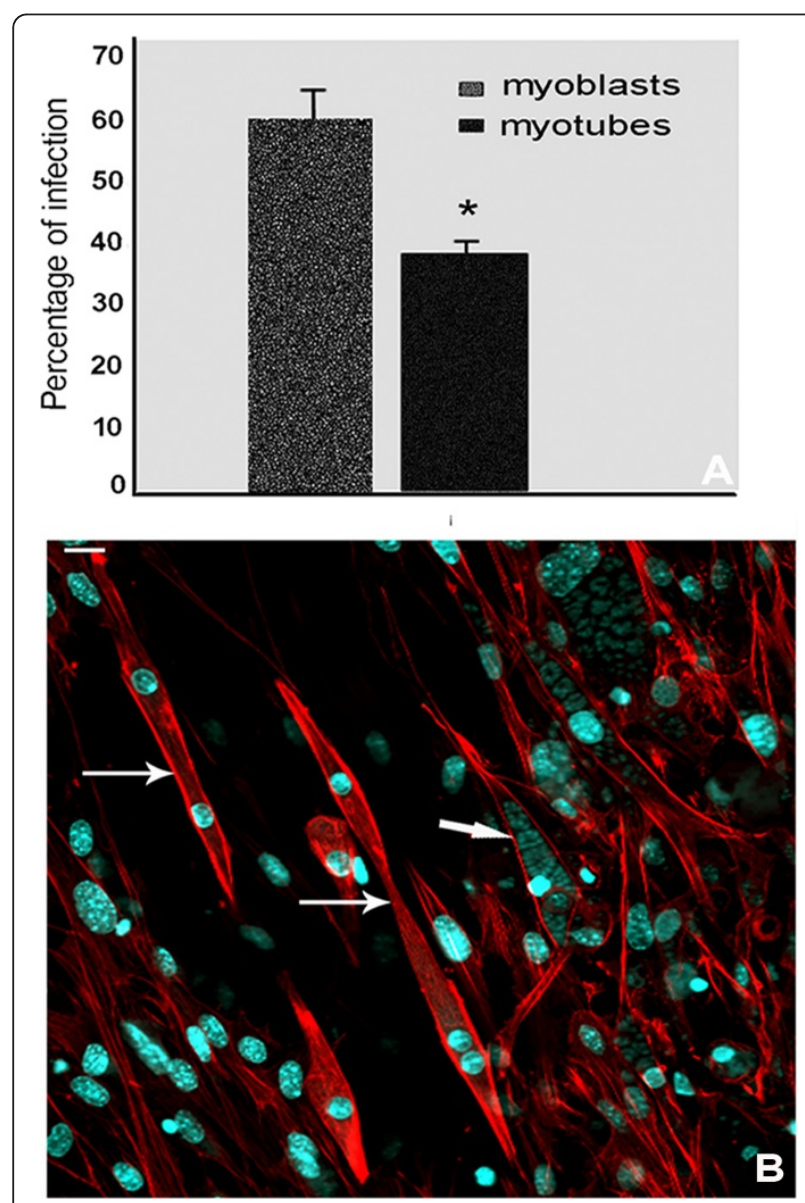

Figure 1 Percentage of T. gondii infected SkMC after $24 \mathrm{~h}$ of interaction. (A) Percentage of myoblasts (61\%) and myotubes (38\%) infected with $T$. gondii after $24 \mathrm{~h}$ of interaction. Student's T-test $\left(^{*}\right) \mathrm{p}$ $\leq 0.05$. (B) Details of SkMC cultures profile observed by fluorescence microscopy with phaloidin-TRITC labeling showing actin filaments in red; nuclei of the cells and the parasites labeled with DAPI, in blue. Infected cultures present myoblasts containing several parasites (thick arrow) and young myotubes with 2 nuclei without parasites (thin arrows). Bars, $20 \mu \mathrm{m}$ uninfected myotubes surrounded by several heavily infected myoblasts after $48 \mathrm{~h}$ of interaction.

\section{Effect of $T$. gondii infection on SkMC myogenesis}

We also analysed the influence of $T$. gondii infection on SkMC myogenesis. Even at low parasite-host cell ratios (1:1), after $24 \mathrm{~h}$ of interaction, the infection percentage was $43 \% \pm 0.06$. In uninfected 3 -day-old cultures the myotube percentage was $19.5 \%$ of the number of total cells. In contrast, infected 3-day-old cultures, after $24 \mathrm{~h}$ of infection, showed only $2.5 \%$ of multinuclear cells, representing an inhibition of $75 \%(p \leq 0.05)$ in myotube formation (Figure 2A). Figure 2B shows that infected myoblasts kept their alignment capacity. Additionally, infected cultures, after $48 \mathrm{~h}$, presented unaltered fusion
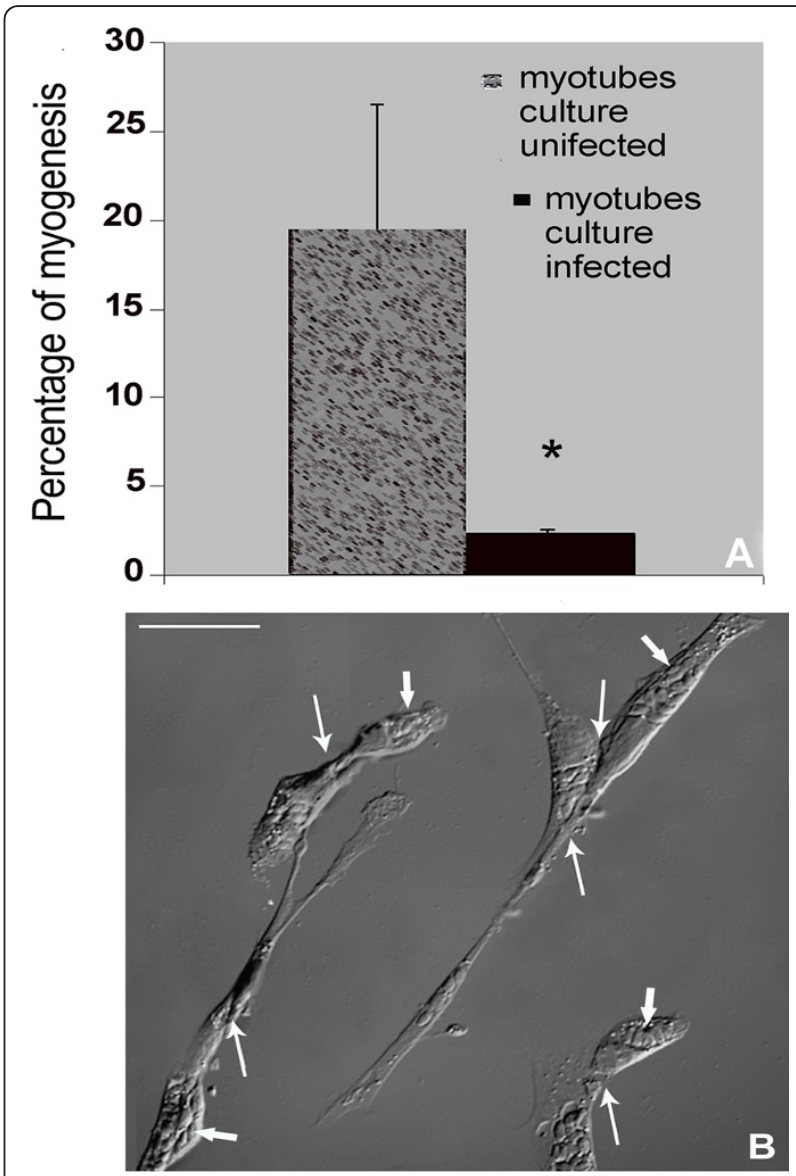

Figure 2 Quantitative analysis of myotube formation percentage during myogenesis in $T$. gondii infected cultures (A) In uninfected cultures, after 3 days, the percentage of myotubes was $19.5 \%$ while in infected cultures, after $24 \mathrm{~h}$ of interaction, this percentage decreased to $2.5 \%$. Note the $75 \%$ reduction in the formation of myotubes in infected cultures. Student's T-test $\left(^{*}\right) p=$ 0.0025. (B) Differential interference contrast (DIC) image showing influence of the infection by T. gondii (24 h of interaction) on SkMC myogenesis. Parasite (thick arrows) and unfused myocytes (thin arrows) 
of non-parasitized myoblasts. The myogenesis course in this case was maintained as demonstrated by myotube existence (Figure 1B).

\section{Detection of cadherin protein in SkMC during infection with $T$. gondii by immunofluorescence analysis} Indirect immunofluorescence assays were performed in order to localize cadherin, an adhesion molecule involved in homophilic recognition during myoblast and myotube fusion. In SkMC 2-day-old cultures, the myoblasts are still in multiplication and differentiation process. Cadherin is strongly revealed in every cell with higher fluorescence intensity in edges near the membrane and at the point of cell-cell contact (Figure 3A). Apparently, the existence of a single, newly internalized parasite did not lead to any change in the profile of cadherin distribution in host cells (Figure 3B), as demonstrated by immunofluorescence microscopy. The same results were maintained during the first $3 \mathrm{~h}$ of interaction (data not shown). After differentiation, myoblasts revealed cadherin highly concentrated at the cell-cell contact point (Figure 4A). However, this profile was not observed after $24 \mathrm{~h}$ of $T$. gondii infection. Besides disorganization, cadherin appeared in aggregates at different points of the SkMC, including around and inside the parasitophorous vacuole (Figure $4 \mathrm{~B}$ and $4 \mathrm{C}$ - inset). Infected myoblasts showed low or no labeling for cadherin at cell-cell contact point (Figure $4 \mathrm{~B}$ and inset and C). Even in cultures infected for $36 \mathrm{~h}$, only uninfected cells present strong cadherin expression (Figure 4D).

During myogenesis in vitro, myoblasts interact with the surface of myotubes. The dynamics of this interaction induces the translocation of cadherin from the extremities of myotubes to the point of cell-cell contact
(Figure 5A, B and inset). Labeling for cadherin was observed at the end of infected myotubes, especially at points of contact with uninfected myoblasts, suggesting migration of cadherin to the sites of possible membrane fusion (Figure 5C-E).

\section{Western blot analysis of cadherin expression in SKMC infected with $T$. gondii}

The total cadherin pool was detected using a pan-cadherin-specific antibody, which recognizes the $130 \mathrm{kDa}$ protein [27], since proteins were extracted from 2-3day-old uninfected cultures (controls) and T. gondii 24 $\mathrm{h}$ infected cultures. Quantitative data obtained by densitometric analysis showed that 3-day-old SkMC presented a reduction of only $10 \%$ in the synthesis of cadherin when compared to 2-day-old cultures. Regarding the participation of Toxoplasma in the modulation of cadherin synthesis, our data showed a significant decline of cadherin expression after $24 \mathrm{~h}$ of $T$. gondiiSkMC interaction, reaching a $54 \%$ reduction. These data demonstrate the variable rate of changes between infected and control SkMC during the analyzed period (Figure 6). For quantitative analysis, western blot signals were normalized against total proteins detected per lane in the corresponding MemCode stained membrane using the QuantityOne software (not shown).

\section{RT-PCR analysis of M-cadherin mRNA in SkMC- T. gondii infected cells}

M-cadherin gene expression in SkMC experimentally infected with $T$. gondii was analyzed by RT-PCR. Mcadherin mRNA was detected 2 and 3 days after plating and it was up regulated only after the induction of myotube formation, which corresponds to the second day of
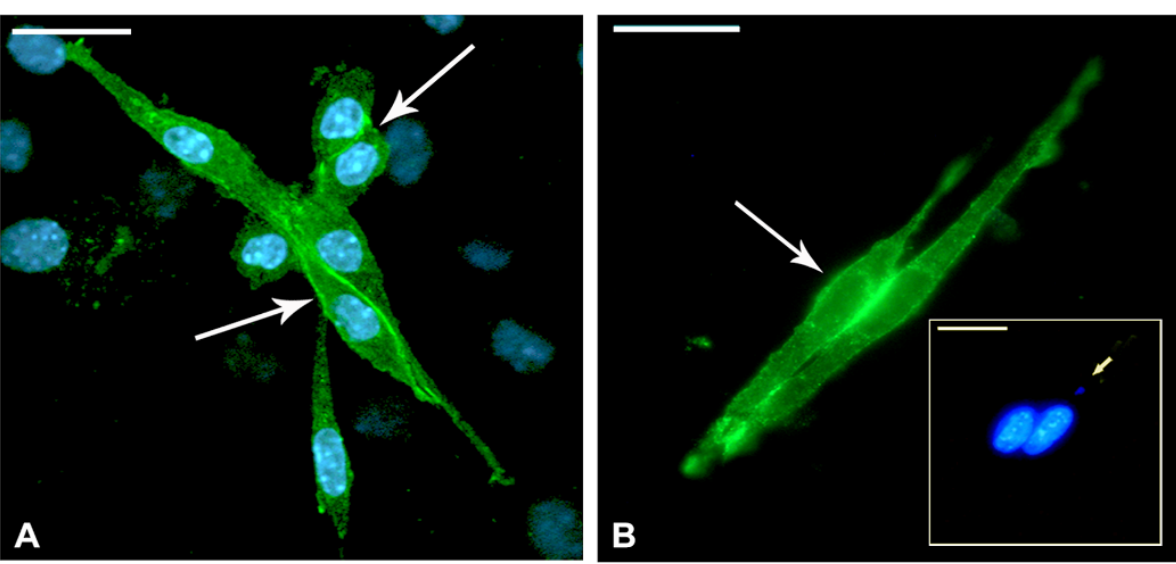

Figure 3 Cadherin localization in primary SkMC cultures. Indirect immunofluorescence assays showing: (A) 2-day-old myoblasts under multiplication and differentiation. Cadherin (in green) is strongly marked in every cell with high concentrations in edges near the membrane and points of cell-cell contact (arrows). (B) apparently, the existence of a single newly internalized parasite (inset) did not lead to any change in the profile of cadherin expression and distribution in host cells (arrow). Nuclei of cells and parasites are labeled with DAPI, in blue. Bars, $20 \mu \mathrm{m}$ 


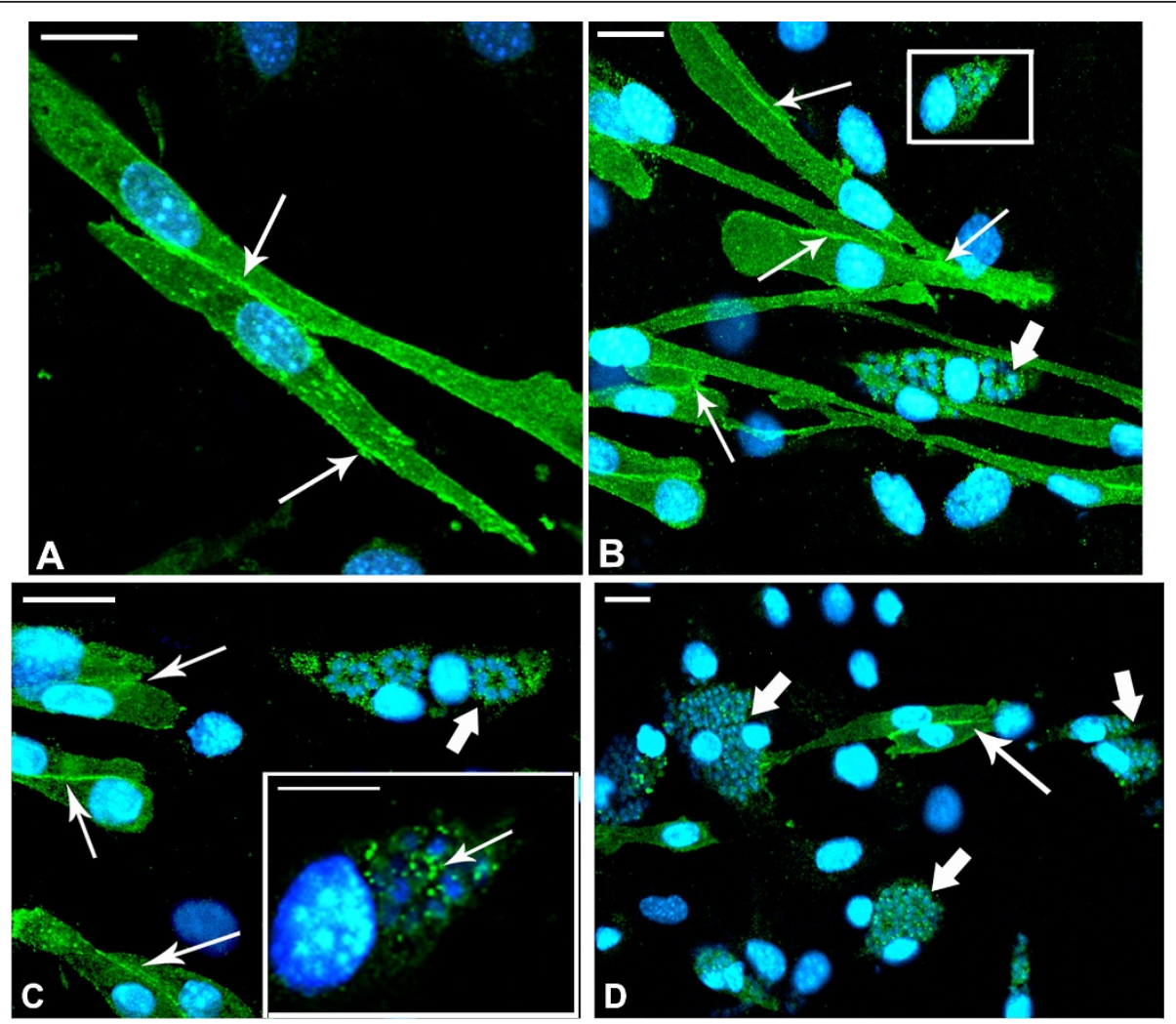

Figure 4 Cadherin distribution in SkMC after $\mathbf{2 4} \mathrm{h}$ of $\boldsymbol{T}$. gondii interaction. Confocal Microscopy analysis showing: (A) In 3-day-old SkMC cultures, after differentiation, myoblasts present intense cadherin labeling at the contact points (arrows). (B and C) In myoblasts after 24 h of interaction with T. gondii (thick arrow), cadherin (thin arrow) becomes disorganized forming aggregates at different sites, around and inside the parasitophorous vacuole (for detail, see inset). (D) Infected myoblasts after $24 \mathrm{~h}$ of interaction with $T$. gondii have little or no labeling for cadherin at points of cell-cell contact (thick arrow). Note that only uninfected cells show strong cadherin expression (thin arrow). Nuclei of cells and parasites labeled with DAPI, in blue. Bars, $20 \mu \mathrm{m}$

culture. After $3 \mathrm{~h}$ of infection with T. gondii M-cadherin mRNA levels were significantly reduced and after $12 \mathrm{~h}$ of interaction, no change in M-cadherin mRNA expression profile was observed. However, after $24 \mathrm{~h}, \mathrm{M}$-cadherin mRNA expression was down regulated when compared to the corresponding SkMC control from 3 day-old cell cultures (Figure 7A-C).

\section{Discussion}

This study analyzes the impact of $T$. gondii-infection on the myogenesis process. The results obtained showed that: (i) myoblasts are more susceptible to infection than myotubes; (ii) $T$. gondii-infected myoblasts are unable to fuse with others myoblasts and myotubes and, (iii) Mcadherin expression is down regulated during infection, indicating that $T$. gondii interferes with myogenesis in SkMC model.

We have observed that after $24 \mathrm{~h}$ of $T$. gondii-SkMC interaction, myoblasts are more infected than myotubes. This difference in infection levels possibly reflects the participation of cell surface molecules from both the parasite and host cells, acting as receptors/ligands, such as intercellular adhesion proteins with Ig domains (ICAM, N-CAM and V-CAM) [36,37]. During infection and transmigration, $T$. gondii interacts with IgCAMs through the adhesion protein MIC2 released from micronemes, suggesting that the parasite infectivity capacity is at least partially dependent on the I-CAM molecules present on the host cell surface [38]. It has been established that during in vivo SkMC differentiation, a change in expression profile of adhesion molecules occurs: N-CAM and V-CAM, as well as cadherins, which are found in higher concentration in myoblasts than myotubes and in adult muscular fibers $[27,29,39-44]$. These data suggest that the different susceptibility of SkMC myoblasts and myotubes to infection by $T$. gondii tachyzoites can be related to the remodeling of adhesion molecule expression profiles on host cell surfaces during their differentiation.

The reproduction of the myogenesis process from mammalian embryonic skeletal muscle cells was demonstrated, as previously reported in both in vivo and in 


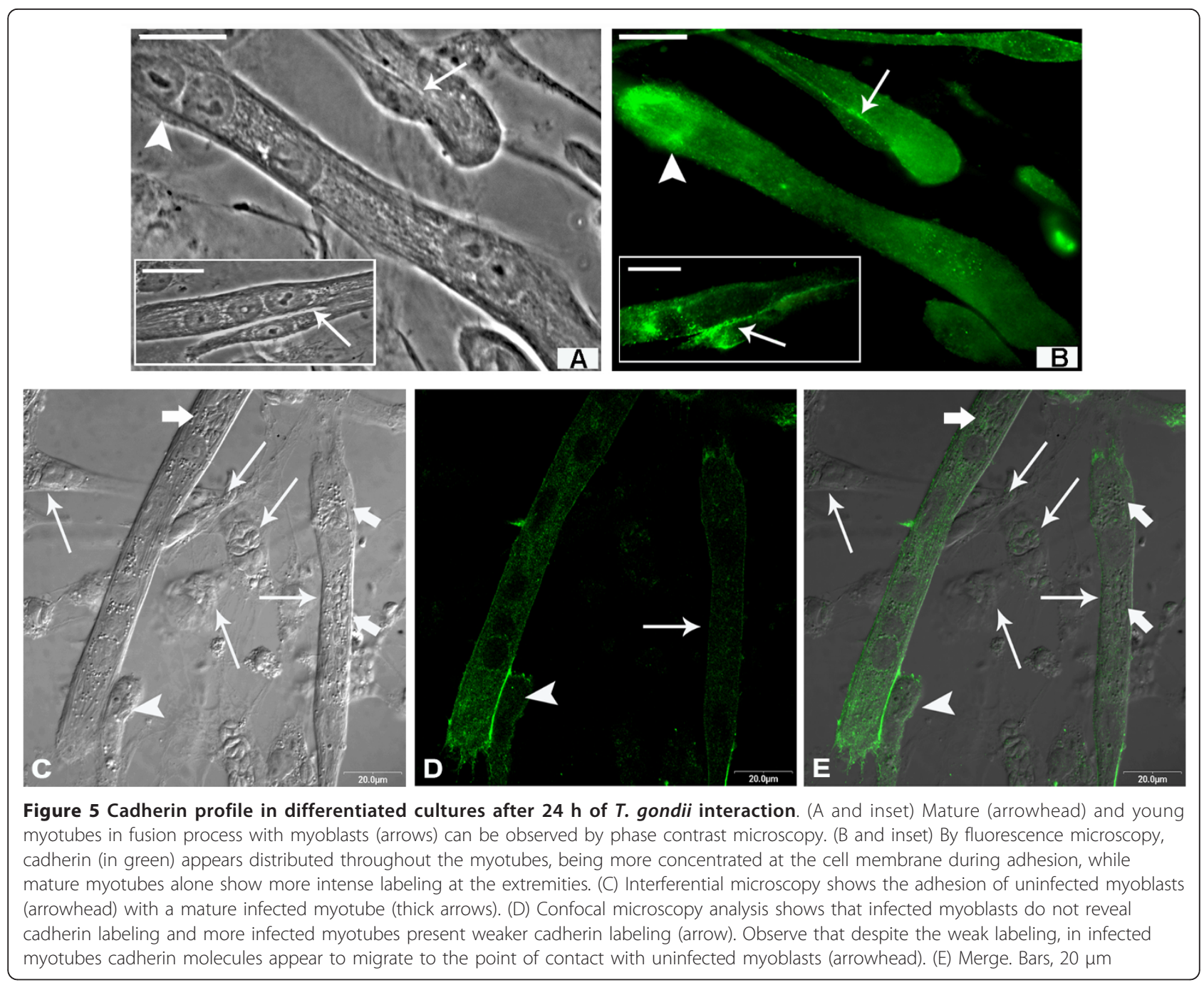

vitro studies [45-47]. It is well known that cadherin plays important roles in morphogenesis, such as cell recognition and cell rearrangement including myogenesis, both in the embryo and in the adult organism during regeneration [20,43,48]. Our results corroborated previous findings demonstrating that antibodies against cadherin protein recognize the same $130 \mathrm{kDa}$ protein [27]. The 10\% reduction observed in the synthesis of cadherin in 2- and 3 day-old cultures can be justified since, after 2 days of plating, some myoblasts have completed their proliferation and recognition programs [26]. In this manner, the infection carried out in cultures after 2 days of plating allowed the study of the role of Toxoplasma in cadherin modulation and inhibition of myogenesis.

We also demonstrated, by immunofluorescence, the distribution of cadherin throughout the myoblast surface, being more concentrated in aligned myoblasts and strongly localized at the point of cell-cell contacts. In young and mature myotubes, cadherin molecules were labeled on the sarcolemma and specifically accumulated at the extremities and on insertion sites of secondary myotubes [27,29,41-44]. In all SkMC (myoblasts and myotubes), no change was observed with respect to the cadherin distribution pattern during the first $3 \mathrm{~h}$ of interaction with $T$. gondii. However, infection of SkMC with $T$. gondii for more than $24 \mathrm{~h}$ resulted in the disruption of cadherin mediated cell junction with a sharp decline in the total cadherin pool. Our results showing, by confocal microscopy, the presence of cadherin around and inside the parasitophorous vacuole, open new perspectives to study the involvement of this adhesion protein during the interaction of T. gondii and muscle cells and also other cellular types not involved with the chronic phase of the disease.

In agreement with our immunofluorescence results, western blot analysis of cadherin expression showed no alteration in protein levels on newly infected myoblasts 


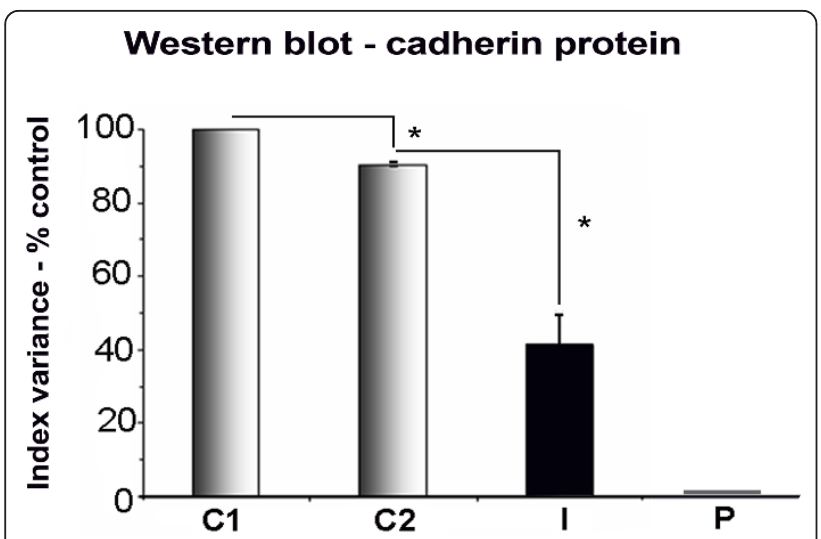

Figure 6 Western blot analysis of cadherin protein expression (A) Percent index variance analysis of the western blot showing cadherin expression: (C1) 2-day old uninfected cultures, (C2) 3-day old uninfected SkMC (control), (I) cultures after $24 \mathrm{~h}$ of interaction with T. gondii tachyzoites, and (P) parasites alone (confirming the absence of synthesis of cadherin by $T$. gondii tachyzoites).

Quantitative analysis revealed only $10 \%$ reduction in the expression of cadherin between normal cultures, reaching values of more than $50 \%$ reduction in T. gondii infected SkMC after $24 \mathrm{~h}$. Results are representative of three independent experiments. Student's T-test $\left(^{*}\right)$ $p \leq 0.05$.

and myotubes (not shown). Nevertheless, a decrease in protein levels was observed after $24 \mathrm{~h}$ of interaction with $T$. gondii, which could lead to membrane fusion inhibition, interfering with the recognition process and fusion of myoblasts. Cultures analyzed after $24 \mathrm{~h}$ of $T$.

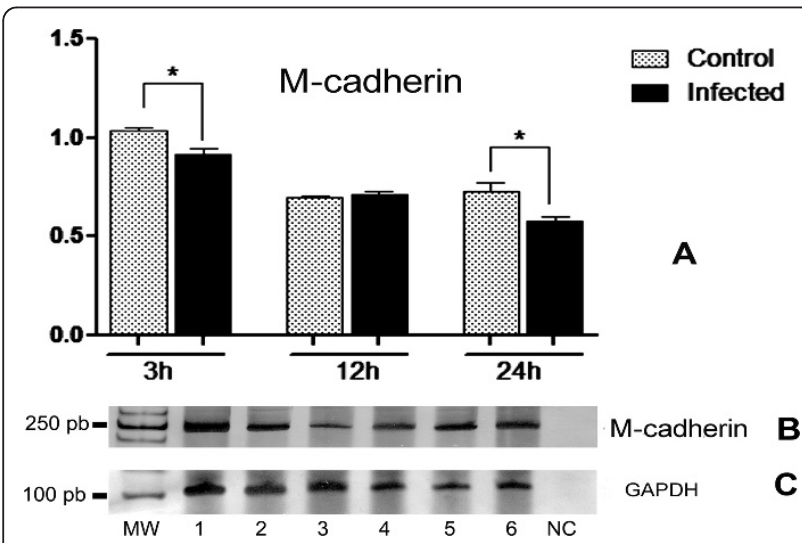

Figure 7 Profile of M-cadherin mRNA expression by SkMC experimentally infected with $T$. gondii. (A) The arbitrary values presented in the graph are based on the densytometric analysis of the PCR gel image shown in panel B, corresponding to 3, 12 and 24 $\mathrm{h}$ of infection. Light bars indicate uninfected control cells and black bars indicate the infected cells. (B) Polyacrylamide, silver stained gels for visualization of the amplified M-cadherin and GAPDH mRNAs (from top to bottom, respectively). Lanes 1, 3 and 5 show the profiles of negative controls and lanes 2, 4 and 6 the profiles of infected cells (3, 12 and 24 h, respectively). NC, negative PCR control. Molecular size markers are indicated to the left. Student's Ttest $\left(^{*}\right) p \leq 0.05$. gondii interaction, showed that the parasite can induce a reduction of more than $50 \%$ in cadherin protein expression, thus interfering with the myogenesis process.

Regarding the negative modulation of cadherin protein expression after $24 \mathrm{~h}$ of $T$. gondii-SkMC interaction, observed by western blot analysis, one factor that must be considered is the activation of proteolytic systems. It is known that, during the $T$. gondii lytic cycle proteolytic systems can be activated by molecules involved in the fusion process, including calcium ions $\left(\mathrm{Ca}^{2+}\right)[49,50]$. Previous works showed that, in response to the cytoplasmic $\mathrm{Ca}^{2+}$ increase in $T$. gondii infected cells, there is an up-regulation of calpain activity which is involved in many biological events, including cell migration and muscle cell differentiation [51-54]. Thus, we suggest that in SkMC infected by T. gondii tachyzoite forms, the reduction observed in the cadherin expression profile may be, among other factors, due to modulation by $\mathrm{Ca}^{2}$ + levels leading to an increase of calpain-3 proteolytic activity $[48,54,55]$. We believe that $T$. gondii, like other pathogens, can benefit from the modulation of cadherin and other adhesion molecules in order to facilitate migration to other neighboring cells and tissue.

Intracellular pathogens, such as Helicobacter pylori, Shigella flexneri, Salmonella typhimurium, Trypanosoma cruzi and Chlamydia trachomatis may module the adhesion junction molecules, such as E-cadherin, claudin-1, ZO-1, N-cadherin and nectin-1 affecting the adherent junctions [21,23,24,56-61]. However, this is not always a consistent behavior. For example, it was observed that in Trichinella pseudospiralis infected satellite cells from muscle cells, M-cadherin was up regulated; the same was not observed for $T$. spiralis, and the authors suggested a differential $\mathrm{M}$-cadherin role in the infection process by different pathogens [25]. Similar to our immunofluorescence results, other authors have observed low or no staining for Pan- and N-cadherin in cardiomyocytes highly infected with $T$. cruzi leading to disruption of cadherin-mediated adheren junctions [24]. In our study, T. gondii infected SkMC after 3 and $24 \mathrm{~h}$ of interaction showed a significant reduction in cadherin mRNA levels, suggesting that $T$. gondii could be involved in the modulation of $\mathrm{M}$-cadherin gene transcription. It has recently been described that $T$. gondii manipulates host signaling pathways, deploying parasite kinases and phosphatases and alters host cell gene transcription through rhoptry proteins $[62,63]$. An example is ROP16 that manipulates the host cell transcription factors STAT3 and STAT6 in the early infection. The rhoptry proteins may alter host cell gene transcription and set up an environment that favors Toxoplasma replication and survival. Another example is the inhibition of STAT1 during T. gondii interaction, which possibly increases its pathogenicity [62-64]. 
During embryonic development the formation and maintenance of muscle tissues primarily requires the action of adhesion proteins such as cadherins [43]. In our in vitro studies using SkMC we verified that $T$. gondii affected the myogenesis process by negatively regulating cadherin expression. Thus, we believe that our results can contribute to a further investigation of congenital infection by Toxoplasma during the embryonic formation of muscle tissue.

\section{Conclusions}

The data of this paper reveal that during the interaction between $T$. gondii tachyzoite forms and primary culture of SkMC, myoblasts are more susceptible to infection than myotubes. These data suggest that the different susceptibility of SkMC myoblasts and myotubes to infection by $T$. gondii can be related: (i) to the remodeling of the host cell's surface adhesion molecule expression profiles during their differentiation; (ii) to the participation of cell surface molecules from both parasite and host cells, acting as receptors/ligands, such as $\mathrm{N}$-CAM and V-CAM, as well cadherins, which are found in higher concentration in myoblasts than myotubes and in adult muscular fibers [27,29,39-42]. We also demonstrated that $T$. gondii SkMC infection down regulates $\mathrm{M}$-cadherin mRNA expression, leading to molecular modifications in the host cell surface which disarray the contact sites between myoblasts and myoblasts-myotubes, promoting the instability of the junctions, which interferes with membrane fusion and consequently inhibiting the myogenesis process. These changes, could lead to the modulation of other molecules contributing to toxoplasmosis pathogenesis in the muscle tissue.

\begin{abstract}
Acknowledgements
The authors thank Carlos Alberto Bizarro Rodrigues from Farmanguinhos/ Fiocruz for the production of interferential microscopy images and Pedro Paulo Manso and Dr. Marcelo Pelajo from PDTIS-Fiocruz Confocal Microscopy Platforms. We are grateful to Sandra Maria de Oliveira Souza and Priscila Lemos for technical assistance. This work was supported with grants from Conselho Nacional de Desenvolvimento Científico e Tecnológico (CNPq), Edital Universal MCT/CNPq n014/2008, Fundação Carlos Chagas Filho de Amparo à Pesquisa do Estado do Rio de Janeiro (FAPERJ), Universidade do Estado do Rio de Janeiro (UERJ), Fundação Oswaldo Cruz (Programa Estratégico de Apoio à Pesquisa em Saúde - PAPES IV), Pronex Programa de Apoio a Núcleos de Excelência - CNPq/FAPERJ and Instituto Oswaldo Cruz/Fiocruz.
\end{abstract}

\section{Author details}

'Laboratório de Biologia Estrutural, Instituto Oswaldo Cruz, Fundação Oswaldo Cruz, (Av. Brasil 4365), Rio de Janeiro (21040-361), Brazil.

${ }^{2}$ Laboratório Cultura de Células, Instituto de Biologia, Universidade do Estado do Rio de Janeiro, (Av. Prof. Manoel de Abreu 444), Rio de Janeiro (20550170), Brazil. 'aboratório de Genômica Funcional e Bioinformática, Instituto Oswaldo Cruz, Fundação Oswaldo Cruz, (Av. Brasil 4365), Rio de Janeiro (21040-361), Brazil.

\section{Authors' contributions}

HSB conceived, participated in the design and coordination of the study and had the general supervision and complete overview of the project. AFG co-conceived the study, carried out most of the experimental work, including the processing of samples and the final illustrations for the manuscript, analyzed data and drafted the manuscript, as part of her PhD thesis. EVG and LC participated in the design of the study. JRC performed western blot analysis. LML carried out the molecular assays. All authors analyzed the data and read and approved the final manuscript.

\section{Competing interests}

The authors declare that they have no competing interests.

Received: 11 January 2011 Accepted: 18 May 2011

Published: 18 May 2011

\section{References}

1. Sukthana Y: Toxoplasmosis: beyond animals to humans. Trends Parasitol 2006, 22:137-142.

2. Barragan A, Sibley LD: Migration of Toxoplasma gondii across biological barriers. Trends Microbiol 2003, 11:426-430.

3. Luft BJ, Hafner R, Korzun AH, Leport C, Antoniskis D, Bosler EM, Bourland DD, Uttamchandani R, Fuhrer J, Jacobson J: Toxoplasmic encephalitis in patients with the acquired immunodeficiency syndrome. N Engl J Med 1993, 329:995-1000

4. Commodaro AG, Belfort RN, Rizzo LV, Muccioli C, Silveira C, Burnier MN Jr, Belfort R Jr: Ocular toxoplasmois: na update and review of the literature. Mem Inst Oswaldo Cruz 2009, 104:345-350.

5. Guimarães EV, de Carvalho L, Barbosa HS: Primary culture of skeletal muscle cells as a model for studies of Toxoplasma gondii cystogenesis. J Parasitol 2008, 94:72-83.

6. Guimarães EV, Carvalho L, Barbosa HS: Interaction and cystogenesis of Toxoplasma gondii within skeletal muscle cells in vitro. Mem Inst Oswaldo Cruz 2009, 140:170-174.

7. Ferreira-da-Silva MF, Barbosa HS, Groß U, Lüder CG: Stress-related and spontaneous stage differentiation of Toxoplasma gondii. Molecular Biosystems 2008, 4:824-834

8. Ferreira-da-Silva MF, Rodrigues RM, Andrade EF, Carvalho L, Groß U, Lüder CG, Barbosa HS: Spontaneous stage differentiation of mousevirulent Toxoplasma gondii RH parasites in skeletal muscle cells: an ultrastructural evaluation. Mem Inst Oswaldo Cruz 2009, 140:196-200.

9. Ferreira-da-Silva MF, Takács AC, Barbosa HS, Gross U, Lüder CG: Primary skeletal muscle cells trigger spontaneous Toxoplasma gondii tachyzoiteto-bradyzoite conversion at higher rates than fibroblasts. Int J Med Microbiol 2009, 299:281-288

10. Remington JS, Cavanaugh EN: Isolation of the encysted form of Toxoplasma gondii from human skeletal muscle and brain. N Engl J Med 1965, 273:1308-1310.

11. Karasawa T, Takizawa I, Morita K, Ishibashi H, Kanayama S, Shikata T: Polymyositis and toxoplasmosis. Acta Pathol Jpn 1981, 31:675-680.

12. Cuturic M, Hayat GR, Vogler CA, Velasques A: Toxoplasmic polymyositis revisited, case report and review of literature. Neuromuscul Disord 1997, 7:390-396.

13. Gherardi R, Baudrimont M, Lionnet F, Salord JM, Duvivier C, Michon C, Wolff M, Marche C: Skeletal muscle toxoplasmosis in patients with acquired immunodeficiency syndrome: a clinical and pathological study. Ann Neurol 1992, 32:535-542.

14. Hassene A, Vital A, Anghel A, Guez S, Series C: Acute acquired toxoplasmosis presenting as polymyositis and chorioretinitis in immunocompetent patient. Joint Bone Spine 2008, 75:603-605.

15. Barbosa HS, Andrade EF, Carvalho L: Ultrastructural aspects of the Toxoplasma gondii-skeletal muscle cells interaction. Mol Biol Cell 1999, 10:182.

16. Barbosa HS, Ferreira-Silva MF, Guimarães EV, Carvalho L, Rodrigues RM: Absence of vacuolar membrane involving Toxoplasma gondii during its intranuclear localization. J Parasitol 2005, 91:182-184.

17. Andrade EF, Stumbo AC, Monteiro-Leal LH, Carvalho L, Barbosa HS: Do microtubules around the Toxoplasma gondii-containing parasitophorous vacuole in skeletal muscle cells form a barrier for the phagolysosomal fusion? J Submicrosc Cytol Pathol 2001, 33:337-341. 
18. Kokta TA, Dodson MV, Gertler A, Hill RA: Intercellular signaling between adipose tissue and muscle tissue. Domest Anim Endocrinol 2004, 27:303-331.

19. Charge SB, Rudnicki MA: Cellular and molecular regulation of muscle regeneration. Physiol Rev 2004, 84:209-238.

20. Gumbiner BM: Regulation of cadherin-mediated adhesion in morphogenesis. Nat Rev Mol Cell Biol 2005, 6:622-634

21. Soler AP, Gilliard G, Xiong Y, Knudsen KA, Martin JL, De Suarez CB, Mota Gamboa JD, Mosca W, Zoppi LB: Overexpression of neural cell adhesion molecule in Chagas' myocarditis. Hum Pathol 2001, 32:149-155.

22. Costa RF, de Souza WM, Benchimol JF, Alderete JA, Morgado-Diaz: Trichomonas vaginalis perturbs the junctional complex in epithelial cells. Cell Res 2005, 15:704-716.

23. Bebb JR, Leach L, Zaitoun A, Hand N, Letley DP, Thomas R, Atherton JC: Effects of Helicobacter pylori on the cadherin-catenin complex. J Clin Pathol 2006, 59:1261-1266.

24. Melo TG, Meirelles MN, Pereira MC: Trypanosoma cruzi alters adherens junctions in cardiomyocytes. Microbes Infect 2008, 10:1405-1410.

25. Wu Z, Nagano I, Takahashi Y: Candidate genes responsible for common and different pathology of infected muscle tissues between Trichinella spiralis and T. pseudospiralis infection. Parasitol Int 2008, 57:368-378.

26. Donalies M, Cramer M, Ringwald M, Starzinski-Powitz A: Expression of Mcadherin, a member of the cadherin multigene family, correlates with differentiation of skeletal muscle cells. Proc Natl Acad Sci USA 1991, 15:8024-8028.

27. Eng H, Herrenknecht K, Semb H, Starzinski-Powitz A, Ringertz N, Gullberg D: Effects of divalent cations on M-cadherin expression and distribution during primary rat myogenesis in vitro. Differentiation 1997, 61:169-176.

28. Charrasse S, Comunale F, Grumbach Y, Poulat F, Blangy A, GauthierRouvière C: RhoA GTPase regulates $\mathrm{M}$-cadherin activity and myoblast fusion. Mol Biol Cell 2006, 17:749-759.

29. Rose O, Rohwedel J, Reinhardt S, Bachmann M, Cramer M, Rotter M, Wobus A, Starzinski-Powitz A: Expression of M-cadherin protein in myogenic cells during prenatal mouse development and differentiation of embryonic stem cells in culture. Dev Dyn 1994, 201:245-259.

30. Magalhães KG, Passos LK, Carvalho-Odos S: Detection of Lymnaea columella infection by Fasciola hepatica through Multiplex-PCR. Mem Inst Oswaldo Cruz 2004, 99:421-424.

31. Nagineni CN, Detrick B, Hooks JJ: Toxoplasma gondii infection induces gene expression and secretion of interleukin 1 (IL-1), IL-6, granulocytemacrophage colony stimulating factor, and intercellular adhesion molecule 1 by human retinal pigment epithelial cells. Infect Immun 2000, 68:407-410.

32. Nishikawa $Y$, Xuenan $X$, Makala L, Vielemeyer $O$, Joiner KA, Nagasawa $H$ : Characterisation of Toxoplasma gondii engineered to express mouse interferon-gamma. Int J Parasitol 2003, 33:1525-1535.

33. Okomo-Adhiambo M, Beattie C, Rink A: cDNA microarray analysis of hostpathogen interactions in a porcine in vitro model for Toxoplasma gondii infection. Infect Immun 2006, 74:4254-4265.

34. Taubert A, Zahner $\mathrm{H}$, Hermosilla C: Dynamics of transcription of immunomodulatory genes in endothelial cells infected with different coccidian parasites. Vet Parasitol 2006, 142:214-222.

35. Taubert A, Krüll M, Zahner H, Hermosilla C: Toxoplasma gondii and Neospora caninum infections of bovine endothelial cells induce endothelial adhesion molecule gene transcription and subsequent PMN adhesion. Vet Immunol Immunopathol 2006, 112:272-283.

36. Hosokawa Y, Hosokawa I, Ozaki K, Nakae H, Matsuo T: Cytokines differentially regulate ICAM- 1 and VCAM-1 expression on human gingival fibroblasts. Clin Exp Immunol 2006, 144:494-502.

37. Sonnet C, Lafuste P, Arnold L, Brigitte M, Poron F, Authier F, Chretien F, Gherardi RK, Chazaud B: Human macrophages rescue myoblasts and myotubes from apoptosis through a set of adhesion molecular systems. J Cell Sci 2006, 119:2497-2507.

38. Charron AJ, Sibley LD: Molecular partitioning during host cell penetration by Toxoplasma gondii. Traffic 2004, 5:855-867.

39. Levi G: Cell adhesion molecules during Xenopus myogenesis. Cytotechnology 1993, 11:91-93.

40. Levi G, Simonneau L, Saint-Jeannet JP, Thiery JP: Molecular transitions accompanying growth of the axial musculature of Xenopus laevis. $C R$ Acad Sci III 1993, 316:822-837.
41. Irintchev A, Zeschnigk M, Starzinski-Powitz A, Wernig A: Expression pattern of $\mathrm{M}$-cadherin in normal, denervated, and regenerating mouse muscles. Dev Dyn 1994, 199:326-337.

42. Jesse $T L$, LaChance $R$, lademarco MF, Dean DC: Interferon regulatory factor-2 is a transcriptional activator in muscle where it regulates expression of vascular cell adhesion molecule-1. J Cell Biol 1998, 140:1265-1276.

43. Kaufmann U, Martin B, Link D, Witt K, Zeitler R, Reinhard S, StarzinskiPowitz A: M-cadherin and its sisters in development of striated muscle. Cell Tissue Res 1999, 296:191-198.

44. Curci R, Battistelli M, Burattini S, D'Emilio A, Ferri P, Lattanzi D, Ciuffoli S, Ambrogini P, Cuppini R, Falcieri E: Surface and inner cell behaviour along skeletal muscle cell in vitro differentiation. Micron 2008, 39:843-851.

45. Meirelles MNL, Barbosa HS, De Souza W, Araujo Jorge TC: Recent contributions for a better understanding of the Trypanosoma cruzimuscle cell interaction. Memórias Inst Oswaldo Cruz 1984, 79:7-11.

46. Araújo Jorge TC, Barbosa HS, Moreira AL, De Souza W, Meirelles MN: The interaction of myotropic and macrophagotropic strains of Trypanosoma cruzi with myoblasts and fibers of skeletal muscle. Z Parasitenkd 1986, 72:577-584.

47. Araya R, Riquelme MA, Brandan E, Sáez JC: The formation of skeletal muscle myotubes requires functional membrane receptors activated by extracellular ATP. Brain Res Brain Res Rev 2004, 47:174-188.

48. Kramerova I, Kudryashova E, Wu B, Spencer MJ: Regulation of the Mcadherin-beta-catenin complex by calpain 3 during terminal stages of myogenic differentiation. Mol Cell Biol 2006, 26:8437-8447.

49. Gail M, Groß U, Bohne W: Transcriptional profile of Toxoplasma-infected human fibroblasts assessed by gene array hybridization. Mol Genet Gen 2001, 265:905-912.

50. Arrizabalaga G, Boothroyd JC: Role of calcium during Toxoplasma gondi invasion and egress. Int J Parasitol 2004, 9:361-368.

51. Delgado EF, Geesink GH, Marchello JA, Goll DE, Koohmaraie M: Properties of myofibril-bound calpain activity in longissimus muscle of callipyge and normal sheep. J Anim Sci 2001, 79:2097-2107.

52. Glading A, Lauffenburger DA, Wells A: Cutting to the chase: calpain proteases in cell motility. Trends Cell Biol 2002, 12:46-54.

53. Liu X, Schnellmann RG: Calpain mediates progressive plasma membrane permeability and proteolysis of cytoskeleton-associated paxillin, talin, and vinculin during renal cell death. J Pharmacol Exp Ther 2003, 304:63-70.

54. Dedieu S, Poussard S, Mazeres G, Grise F, Dargelos E, Cottin P, Brustis JJ: Myoblast migration is regulated by calpain through its involvement in cell attachment and cytoskeletal organization. Exp Cell Res 2004, 292:187-200.

55. Raynaud F, Carnac G, Marcilhac A, Benyamin Y: m-Calpain implication in cell cycle during muscle precursor cell activation. Exp Cell Res 2004, 298:48-57.

56. Jepson MA, Collares-Buzato CB, Clark MA, Hirst BH, Simmons NL: Rapid disruption of epithelial barrier function by Salmonella typhimurium is associated with structural modification of intercellular junctions. Infect Immun 1995, 63:356-359.

57. Terres AM, Pajares JM, O'Toole D, Ahern S, Kelleher D: $H$. pylori infection is associated with downregulation of E-cadherin, a molecule involved in epithelial cell adhesion and proliferation control. J Clin Pathol 1998, 51:410-412.

58. Sears $\mathrm{CL}$ : Molecular physiology and pathophysiology of tight junctions $\mathrm{V}$. Assault of the tight junction by enteric pathogens. Am J Physiol Gastrointest Liver Physiol 2000, 279:1129-1134.

59. Prozialeck WC, Fay MJ, Lamar PC, Pearson CA, Sigar I, Ramsey KH: Chlamydia trachomatis disrupts $\mathrm{N}$-cadherin dependent cell-cell junctions and sequesters b-catenin in human cervical epithelial cells. Infect Immun 2002, 70:2605-2613.

60. Sakaguchi T, Kohler H, Gu X, McCormick BA, Reinecker HC: Shigella flexneri regulates tight junction-associated proteins in human intestinal epithelial cells. Cell Microbiol 2002, 4:367-381.

61. Sun J, Kintner J, Schoborg RV: The host adherens junction molecule nectin-1 is downregulated in Chlamydia trachomatis-infected genital epithelial cells. Microbiology 2008, 54:1290-1299.

62. Saeij JP, Coller S, Boyle JP, Jerome ME, White MW, Boothroyd JC: Toxoplasma co-opts host gene expression by injection of a polymorphic kinase homologue. Nature 2007, 445:324-327. 
63. Laliberté J, Carruthers VB: Host cell manipulation by the human pathogen Toxoplasma gondii. Cell Mol Life Sci 2008, 65:1900-1915.

64. Sibley LD, Qiu W, Fentress S, Taylor SJ, Khan A, Hui R: Forward genetics in Toxoplasma gondii reveals a family of rhoptry kinases that mediates pathogenesis. Eukaryot Cell 2009, 8:1085-1093.

doi:10.1186/1471-2180-11-110

Cite this article as: Gomes et al:: Toxoplasma gondii down modulates

cadherin expression in skeletal muscle cells inhibiting myogenesis. BMC Microbiology 2011 11:110.

Submit your next manuscript to BioMed Central and take full advantage of:

- Convenient online submission

- Thorough peer review

- No space constraints or color figure charges

- Immediate publication on acceptance

- Inclusion in PubMed, CAS, Scopus and Google Scholar

- Research which is freely available for redistribution 